\title{
Recent decade of growth and calcification of Orbicella faveolata in the Florida Keys: an inshore-offshore comparison
}

\author{
Derek P. Manzello ${ }^{1, *}$, Ian C. Enochs ${ }^{1,2}$, Graham Kolodziej ${ }^{1,2}$, Renée Carlton ${ }^{1,2}$ \\ ${ }^{1}$ Atlantic Oceanographic and Meteorological Laboratories (AOML), NOAA, 4301 Rickenbacker Cswy., Miami, FL 33149, USA \\ ${ }^{2}$ Cooperative Institute for Marine and Atmospheric Studies, Rosenstiel School of Marine and Atmospheric Science, \\ University of Miami, 4600 Rickenbacker Cswy., Miami, FL 33149, USA
}

\begin{abstract}
Coral reefs along the Florida Keys portion of the Florida Reef Tract (FRT) have undergone a dramatic decline since the 1980s. Since the 1997-1998 El Niño event, coral cover on offshore reefs of the FRT has been $\leq 5 \%$ and continues to decline. Mortality of the frameworkconstructing coral in the Orbicella (formerly Montastraea) annularis species complex has driven this recent loss in overall coral cover. One exception to this decline occurred on the inshore patch reefs of the Florida Keys, where coral cover has remained relatively high. We examined the growth and calcification of Orbicella faveolata, an ecologically important subspecies of the $O$. annularis complex, at both an inshore and an offshore reef site representing this dichotomy of present-day coral cover. The period examined (2004 to 2013) encompasses the Caribbean-wide 2005 mass coral bleaching, the 2009-2010 catastrophic cold-water bleaching, and a warm-water bleaching event in 2011. Extension and calcification rates were higher inshore every year from 2004 to 2013 except when there were thermal stress events that solely impacted inshore reefs (as in 2009-2010 and 2011). Inshore growth rates recovered quickly from cold and warm-water stress. These higher calcification rates and their quick recovery after thermal stress are likely important factors in the persistence of high coral cover inshore.
\end{abstract}

KEY WORDS: Florida Reef Tract · Coral bleaching · Thermal stress · Cheeca Rocks · Orbicella (Montastraea) annularis species complex

\section{INTRODUCTION}

Coral reefs throughout the Caribbean, including those along the Florida Keys portion of the Florida Reef Tract (FRT), have been in decline since the 1980s (Dustan \& Halas 1987, Porter \& Meier 1992, Gardner et al. 2003). This has been attributed to coral disease, warm water bleaching, and, more contentiously, declining water quality and overfishing (Pandolfi et al. 2005, Precht \& Miller 2007). Warmwater coral bleaching events, in particular, have increased in frequency and severity on the FRT since the 1980s. Isolated, small-scale bleaching events were reported in 1961, 1973, and 1983 (Shinn 1966, Jaap 1979, 1985). There have been 5 Keys-wide warm-water coral bleaching events from 1987 to 2013 (1987, 1990, 1997, 1998, and 2005), with localized events reported in the interim (Causey 2001, Manzello et al. 2007a,b). While widespread warmwater bleaching did not occur from 2006 to 2013, there were qualitative reports of moderate bleaching every year except 2013 (Walter 2014).

Coral cover on the FRT has been $\leq 5 \%$ since the 1997/98 El Niño on offshore reefs and has continued to decline (Somerfield et al. 2008, Ruzicka et al. 2013). This most recent decline was driven by mortal- 
ity of the Orbicella (formerly Montastraea) annularis species complex (Ruzicka et al. 2013, Toth et al. 2014). The loss of the $O$. annularis species complex has occurred across the Caribbean (Bruckner \& Bruckner 2006, Edmunds \& Elahi 2007, Bruckner \& Hill 2009). An exception to this trend is the inshore patch reefs that are located between the islands of the Florida Keys and the offshore reefs. Since the 1997/98 El Niño, average coral cover on the patch reefs has ranged from 15 to $35 \%$, with some reefs having values $>40 \%$ (Lirman \& Fong 2007, Ruzicka et al. 2013). This high coral cover is enigmatic because inshore sites experience greater thermal variability, increased turbidity/depressed light, increased sedimentation, and elevated nutrients (Shinn 1966, Hudson 1982, Lirman \& Fong 2007).

We examined the growth and calcification of $O$. faveolata over 2004 to 2013 from 2 reef sites that represent the dichotomy of present-day coral cover on the FRT. The long-term growth dynamics of $O$. annularis and $O$. faveolata on the FRT were previously investigated (Hudson 1981, Helmle et al. 2011), but these studies did not address growth from 1997 onward. The period we examine incorporates the Caribbean-wide 2005 mass coral bleaching event, the 2009-2010 cold-water bleaching, and localized warm-water bleaching in 2011 (Manzello et al. 2007b, Kemp et al. 2011, Lirman et al. 2011, Colella et al. 2012). These multiple thermal stress events provide an opportunity to measure the growth response of this threatened species across sites with differing disturbance histories and environmental conditions. We hypothesized that the calcification rates of $O$. faveolata would be greater inshore, where coral cover is higher, relative to offshore.

\section{MATERIALS AND METHODS}

\section{Coral growth}

Small coral cores (3 cm diameter, $10 \mathrm{~cm}$ length) were obtained from live Orbicella faveolta colonies on 5 May 2014 at an offshore reef site $(\mathrm{n}=12$ cores, Little Conch Reef: $24.9465^{\circ} \mathrm{N}, 80.50207^{\circ} \mathrm{W}$, depth $=5$ to $6 \mathrm{~m}$ ) and an inshore patch reef with high coral cover $\left(\mathrm{n}=11\right.$ cores, Cheeca Rocks: $24.897377^{\circ} \mathrm{N}, 80$. $61801^{\circ} \mathrm{W}$, depth $=4$ to $5 \mathrm{~m}$ ) (Fig. 1). We followed the convention of Lirman \& Fong (2007), who identified 2 reef types: inshore patch reefs and offshore bankbarrier reefs. The bank-barrier reefs occur along the seaward edge of the shelf, whereas the patch reefs are within the inner lagoon (Hawk Channel) between the Florida Keys and outer bank reefs (Marszalek et al. 1977). Inshore is defined as $<4.5 \mathrm{~km}$ and offshore as $>4.5 \mathrm{~km}$ from shore. Cheeca Rocks is 2 to $2.5 \mathrm{~km}$ from shore, whereas Little Conch Reef is $\sim 6 \mathrm{~km}$ from shore. The distance from channels between the islands of the Florida Keys is a major determinant of patch reef abundance. There are

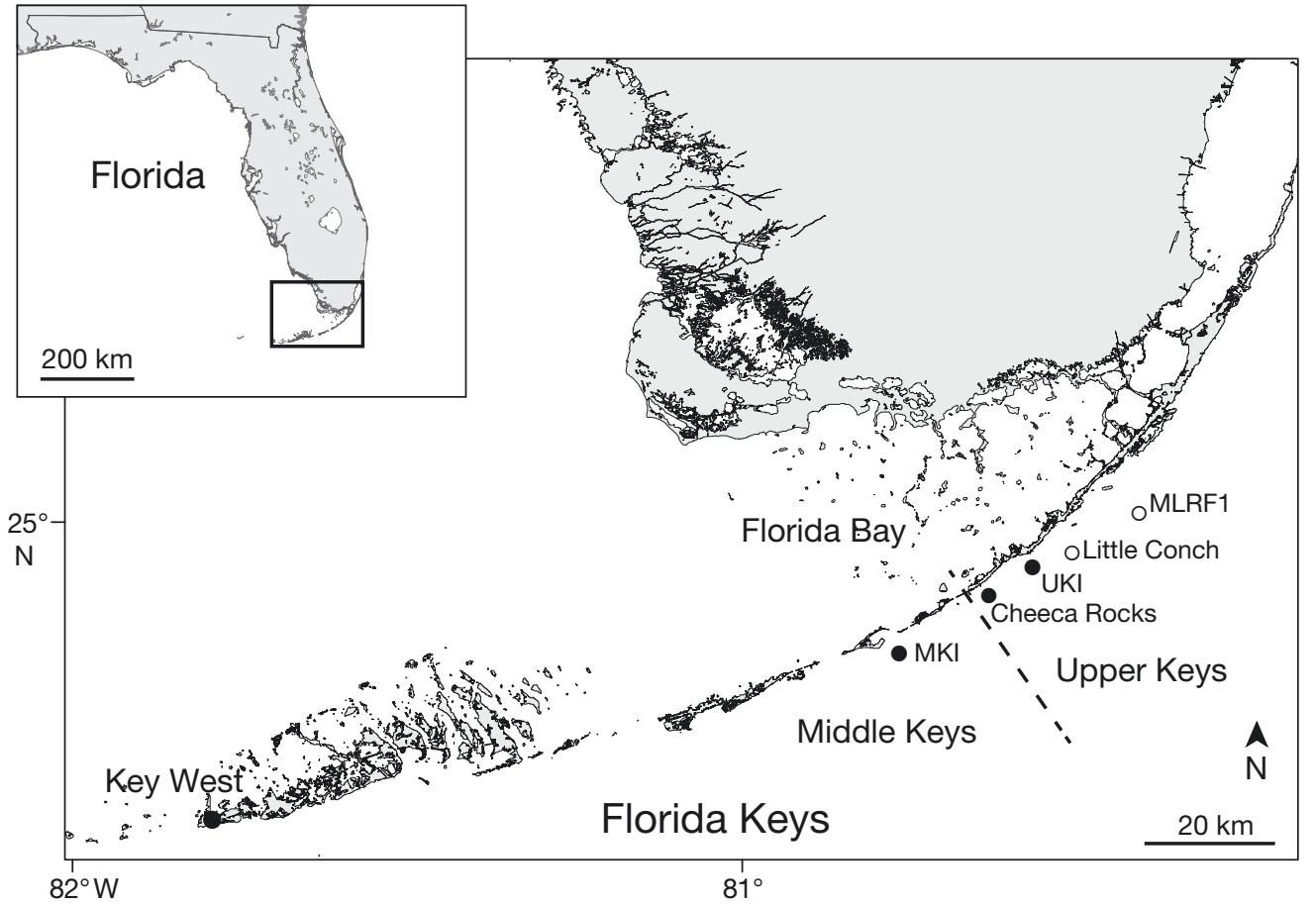

Fig. 1. Florida Keys sites where coral cores and temperature measurements were made. Temperature was measured at all 5 sites; MLRF1: Molasses Reef Coastal-Marine Automated Network (C-MAN); UKI: Upper Keys Inshore; MKI: Middle Keys Inshore. Coral cores were collected from Cheeca Rocks and Little Conch Reef. Solid circles are inshore sites, open circles are offshore sites 
$>1000$ patch reefs in the upper Florida Keys where there are no channels, whereas in the middle Keys, where there are wide channels between islands, there are 50 to 115 (Marszalek et al. 1977, Lirman \& Fong 2007).

Cores were obtained with a pneumatic hand-drill with a diamond coring bit connected to a SCUBA tank from the top of each colony along the growth axis. Colonies that were $>1 \mathrm{~m}$ in diameter and height, without visible macroborers, were cored haphazardly from each reef over a spatial area of approximately $5000 \mathrm{~m}^{2}$. Each colony sampled was at least 3 to $4 \mathrm{~m}$ from another sampled coral. Core holes were filled with concrete plugs and epoxy. Filling core holes prevents the recruitment of boring organisms that can damage coral tissue or weaken the skeleton (e.g. Hudson 1981). Upon collection, the cores were carefully stored in plastic bags and returned to the lab in Miami. Cores were cut into $1 \mathrm{~cm} \times 2 \mathrm{~cm} \times$ $10 \mathrm{~cm}$ slabs using a tile saw and scanned using a Skyscan 1174 micro-CT with a $50 \mathrm{kV} 800 \mu \mathrm{A}$ X-ray source at a resolution of $64.2 \mu \mathrm{m}$. X-ray transmission is a function of transmission strength and thickness and density of the object X-rayed. Due to the constraints of our machine, noise-free transmission was achieved at $1 \times 2 \mathrm{~cm}$ sample thickness. X-ray images were collected every $0.5^{\circ}$ over a $180^{\circ}$ rotation and reconstructed into an image stack using NRecon (Skyscan software). Image stacks were rotated and recut so that transaxial images were perpendicular to the growth axis. Recut image stacks were imported into CTAn (Skycan software) where a 3D region of interest (ROI) was defined encompassing the entire slab. The ROI was chosen parallel to the growth axis, incorporating as many corallites as possible. ROIs avoided areas that would impact density or blur annual banding, like borings or corallite 'fans' (e.g. Lough \& Barnes 1997). Density was calibrated to Xray attenuation coefficient by linear regression of 3 coral samples of known density (determined using dry weight and wax dipping by Manzello 2010a; $P$. lobata, $1.13 \mathrm{~g} \mathrm{~cm}^{-3}$; Pavona clavus, $1.59 \mathrm{~g} \mathrm{~cm}^{-3}$; Pavona gigantea, $1.34 \mathrm{~g} \mathrm{~cm}^{-3}$ ) as well as air (a zero reference point). Mean density was recorded from within each 2D ROI from each transaxial image in the stack. Density was plotted as a function of the depth of each transaxial image. Density/depth data were imported into CoralXDS (Helmle et al. 2002), where years were delineated using the peak-to-peak (highdensity band to high-density band) method. The distance between high-density peaks was used as

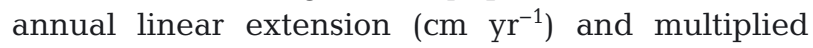
by bulk density to estimate annual calcification rates $\left(\mathrm{g} \mathrm{cm}^{-2} \mathrm{yr}^{-1}\right)$ (e.g. Dodge \& Brass 1984). High-density bands form in late summer for $O$. annularis in the Florida Keys (Hudson et al. 1976). Thus each annual increment integrates growth from late summer of one year to late summer of the next year.

\section{Temperature data}

Seawater temperature was measured in situ every 30 min using HOBO Pro V2 thermistors (Onset) from June 2010 through August 2013 at Little Conch Reef, as well as at sites immediately to the north (Upper Keys Inshore [UKI]: $24.93898^{\circ} \mathrm{N}, 80.56272^{\circ} \mathrm{W}$ ) and south of Cheeca Rocks (Middle Keys Inshore [MKI]: $24.81216^{\circ} \mathrm{N}, 80.76075^{\circ} \mathrm{W}$; both sites depths $=4$ to $5 \mathrm{~m}$ ) (Fig. 1). Thermistors were affixed to rebar that had been hammered into the reef and were $0.5 \mathrm{~m}$ off the bottom. Temperature was measured every $3 \mathrm{~h}$ at Cheeca Rocks (depth $=1 \mathrm{~m}$ ) from 8 December 2011 to 31 May 2012 and 9 December 2012 to August 2013 using a conductivity-temperature sensor (Model SBE-16 plus v. 2.2, Seabird Electronics). We compared daily average temperatures from Cheeca Rocks with the other 2 inshore sites individually and combined to determine the best proxy for temperatures at Cheeca Rocks. The average of the 2 sites provided the best fit when regressed against the Cheeca Rocks data $\left(\mathrm{r}^{2}=0.99, \mathrm{n}=372, \mathrm{p}<0.001\right)$. The median and mean difference between Cheeca Rocks and the average temperature from the 2 inshore sites was 0.02 and $0.03^{\circ} \mathrm{C}$, respectively. Mean and median temperatures at the UKI site were 25.26 and $24.80^{\circ} \mathrm{C}$, respectively, whereas they were 25.32 and $24.89^{\circ} \mathrm{C}$ at MKI and 25.35 and $24.81^{\circ} \mathrm{C}$ at Cheeca Rocks.

Hourly sea temperature data from the Molasses Reef C-MAN station (MLRF1, 1 m depth; Fig. 1), an offshore reef, are available nearly continuously since 1988 (www.ndbc.noaa.gov), allowing us to put our $3 \mathrm{yr}$ of data into a longer-term context. The climatology for MLRF1 was determined as previously described (Manzello et al. 2007a). A bleaching threshold was determined for MLRF1 as a monthly mean temperature of $30.4^{\circ} \mathrm{C}$ (Manzello et al. 2007a). To determine if this threshold was exceeded, we calculated the running $30 \mathrm{~d}$ mean sea temperature for each site.

\section{Statistical analysis}

Statistical analyses were performed using Sigma Plot 12. We utilized the Durbin-Watson statistic to 
test for temporal autocorrelation, which can occur in growth time-series (e.g. Lough \& Barnes 1997), but our data did not exhibit temporal autocorrelation. Student $t$-tests were used to compare annual growth between inshore and offshore sites because the data conformed to the assumptions of normality and homoscedasticity.

\section{RESULTS}

\section{Temperature data}

The FRT experiences a large seasonal amplitude in temperature that increases with proximity to shore (Table 1, Fig. 2). Molasses Reef (MLRF1) exceeded the $30.4^{\circ} \mathrm{C}$ threshold in 2011, coincident with bleaching at Cheeca Rocks (D. P. Manzello pers. obs.). Bleaching was not observed, however, at Little Conch Reef. Seven of the 10 summers from 2004 to 2013 were warmer than the climatology at MLRF1 (2004-2007 and 2009-2011), and the bleaching threshold was reached in 3 of these years (2005, 2007, and 2011) (Fig. 2).

Table 1. Sea temperatures $\left({ }^{\circ} \mathrm{C}\right)$ at Cheeca Rocks, Little Conch Reef, and Molasses Reef (MLRF1) from the summer of 2010 through the winter of 2012-13. Min. or Max.: minimum values reported for winter; maximum values reported for summer

\begin{tabular}{|lccccc|}
\hline $\begin{array}{l}\text { Site } \\
\text { Year }\end{array}$ & Season & $\begin{array}{c}\text { Daily } \\
\text { mean }( \pm \text { SD) })\end{array}$ & $\begin{array}{c}\text { Min. } \\
\text { or } \\
\text { Max. }\end{array}$ & $\begin{array}{c}\text { 30 min } \\
\text { measurements } \\
\text { Min. or Max. }\end{array}$ & $\begin{array}{c}\text { Running } \\
\text { Min. or Max. } \\
\text { Cheeca Rocks }\end{array}$ \\
2010 & & & & & \\
$2010-11$ & Summer & $30.82(1.021)$ & 33.38 & 33.91 & 31.68 \\
2011 & Winter & $21.54(1.936)$ & 16.58 & 15.71 & 18.69 \\
$2011-12$ & Summer & $30.95(0.917)$ & 33.03 & 33.48 & 31.76 \\
2012 & Winter & $22.95(1.710)$ & 18.17 & 17.45 & 21.43 \\
$2012-13$ & Summer & $30.19(1.221)$ & 32.77 & 33.40 & 31.32 \\
Little Conch & Winter & $22.90(1.352)$ & 19.73 & 19.20 & 22.18 \\
2010 & & & & & \\
$2010-11$ & Summer & $30.33(0.659)$ & 32.17 & 32.85 & 30.90 \\
2011 & Winter & $22.30(1.297)$ & 18.34 & 17.75 & 21.39 \\
$2011-12$ & Summer & $30.45(0.671)$ & 31.43 & 31.94 & 30.91 \\
2012 & Winter & $23.72(1.403)$ & 19.95 & 18.46 & 22.59 \\
$2012-13$ & Summer & $29.63(0.858)$ & 31.17 & 31.59 & 30.41 \\
MLRF1 & Winter & $23.73(1.069)$ & 21.12 & 19.98 & 22.80 \\
2010 & & & & & \\
$2010-11$ & Summer & $29.93(0.415)$ & 30.74 & N/A & 30.3 \\
2011 & Winter & $22.50(1.004)$ & 22.50 & N/A & 21.9 \\
$2011-12$ & Summer & $30.08(0.639)$ & 31.05 & N/A & 30.7 \\
2012 & Winter & $24.24(0.785)$ & 21.88 & N/A & 23.5 \\
$2012-13$ & Summer & $29.14(0.587)$ & 30.32 & N/A & 29.8 \\
\hline
\end{tabular}

The winter of 2009-2010 was the coldest in the 27 yr temperature record from MLRF1. From the winter of 2008-2009 through the summer of 2011, there was an increase in seasonality at MLRF1, with 3 consecutive cold winters and 3 consecutive warm summers (Fig. 2). This pattern was unprecedented in the MLRF1 record.

\section{Coral growth data}

Rates of extension and calcification were higher at Cheeca Rocks every year from 2004 to 2013 except when there were thermal stress events that impacted Cheeca Rocks and not Little Conch Reef (Fig. 3). The cold-water event of 2009 to 2010 and warm-water bleaching in 2011 impacted growth at Cheeca Rocks, but not Little Conch Reef. The 2011 warm-water bleaching at Cheeca Rocks led to the only year of growth where extension and calcification rates were significantly greater at Little Conch Reef ( $t$-tests; Extension: $t=2.30, \mathrm{p}<0.05$; Calcification: $t=2.83, \mathrm{p}$ $<0.01 ; \mathrm{df}=10$ for both). A similar depression in extension and calcification was evident at both sites from the 2005 bleaching, but the 2005 event impacted growth at Cheeca Rocks far less than the 2011 event (Fig. 3).

Despite the contrasting disturbance histories from 2004 to 2013, overall mean extension and calcification rates were higher at Cheeca Rocks, albeit not significantly (Table 2). When the annual increments of growth associated with thermal stress specific to only Cheeca Rocks were removed (2009-2010, 2011-2012: Table 2), mean extension and calcification were significantly greater at Cheeca Rocks ( $t$-tests; Extension: $t=$ 3.75, $\mathrm{p}<0.01$; Calcification, $t=3.94$, $\mathrm{p}<0.001$; df = 12 for both). Density was similar with and without the stress periods included in the analysis. All growth parameters from 2004 to 2013 at Little Conch Reef were unchanged when the years 2009-2010 and 2011-2012 were removed. Density was greater offshore except for 2005 to 2007, and the overall mean difference between sites from 2004 to 2013 was significant $(t=3.12, \mathrm{p}<0.01, \mathrm{df}=16)$. 


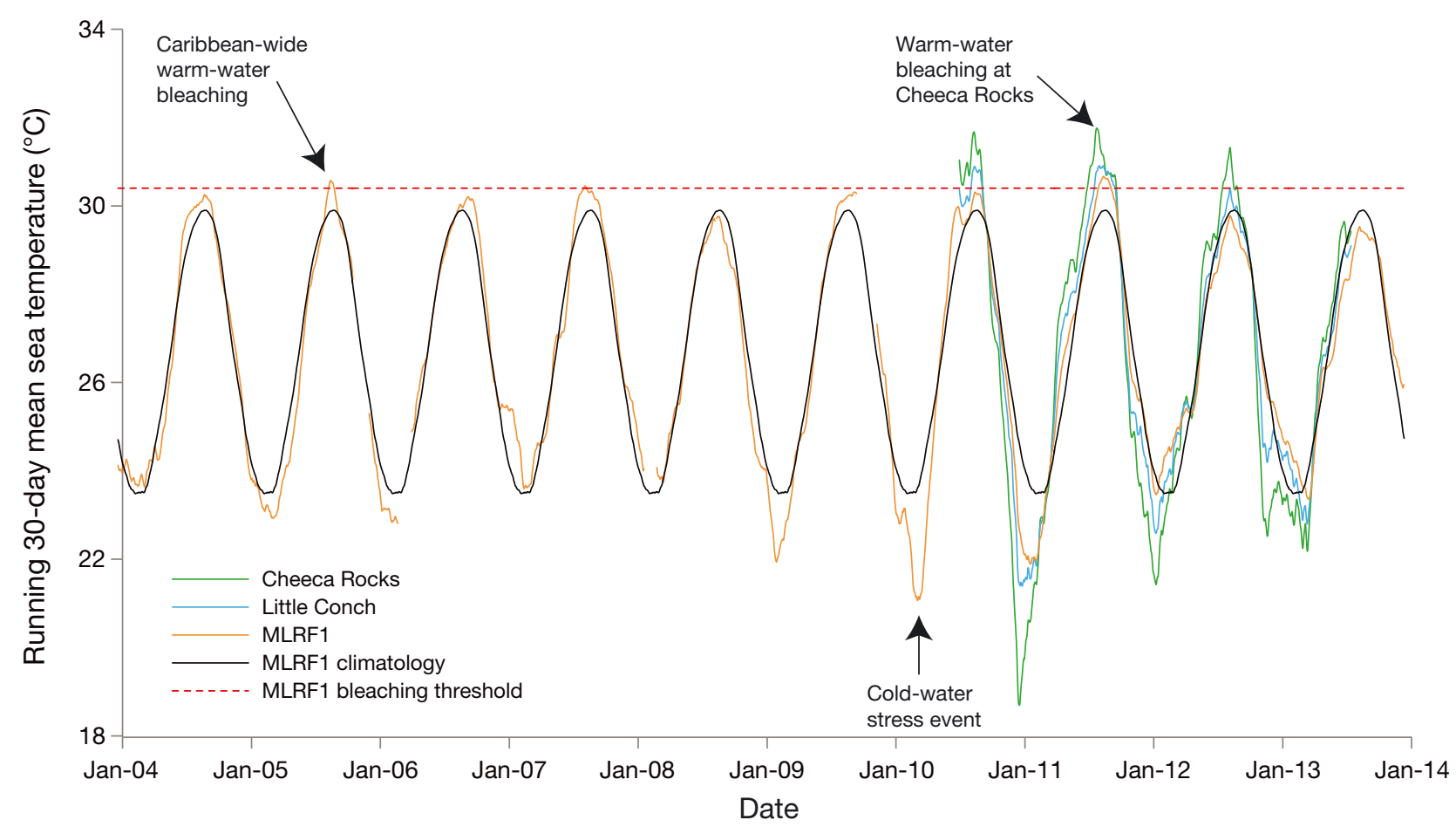

Fig. 2. Running $30 \mathrm{~d}$ mean sea temperatures $\left({ }^{\circ} \mathrm{C}\right)$ for Molasses Reef (2004 to 2013), Cheeca Rocks and Little Conch Reef $(2010$ to 2013). Also shown is the climatology for Molasses Reef (MLRF1 Climatology) and the locally derived bleaching threshold

\section{DISCUSSION}

The growth and calcification of Orbicella faveolata at Cheeca Rocks was greater than at the offshore site and markedly resilient to both cold- and warm-water thermal stress, as rates rebounded in the year following a stress event to near or greater than pre-stress rates. The highest rates of extension and calcification at both sites occurred in 2012 and 2013, which coincided with temperatures at MLRF1 that were similar to the climatology for 2 consecutive years $(2012$ \& 2013; Fig. 2). This was the only time in the period 2004 to 2013 when there were 2 consecutive years without temperatures that were colder or warmer than the climatology.

The extremely cold winter of 2009 to 2010, which caused catastrophic mass mortality of corals on many inshore patch reefs, depressed rates of extension and calcification at Cheeca Rocks. Despite this depression, extension and calcification rates were no different between Cheeca Rocks and Little Conch in 2009-2010 (Fig. 3). Cheeca Rocks did not experience a mass mortality of corals during this event because it was located outside of the area where sea temperatures were coldest that was just slightly to the northeast (Lirman et al. 2011). Recent mortality was $14.2 \%$ when Cheeca Rocks was surveyed in February 2010
(FRRP 2014). Offshore reefs did not experience cold enough conditions to cause bleaching, mortality, or significant reductions in the physiological function of O. faveolata (Lirman et al. 2011, Kemp et al. 2011, Colella et al. 2012).

Mean coral cover at Cheeca Rocks was $42.9 \%$ from 2006 to 2011 (FRRP 2014), and the $O$. annularis species complex accounted for $>70 \%$ of this cover in 2012 (D. P. Manzello unpubl. data). Conversely, coral cover at Conch Reef was very low from 2004 to 2011, ranging from 1.1 to $2.9 \%$ (CREMP 2014). The growth rates of $O$. faveolata at this site were lower than at Cheeca Rocks except when Cheeca Rocks experienced thermal stress that did not occur offshore. The elevated extension and calcification rates, coupled with the quick recovery in growth after thermal stress, are likely important factors to the maintenance of high coral cover at Cheeca Rocks.

Several hypotheses have been proposed to explain the persistence of high coral cover on the inshore patch reefs of the Florida Keys. It has been suggested that the high temperature variance at the inshore patch reefs may have led to thermal acclimatization and/or adaptation, resulting in an increased resistance to thermal stress (Lirman \& Fong 2007, Soto et al. 2011). Others have proposed that the elevated turbidity inshore may lead to higher heterotrophic feed- 

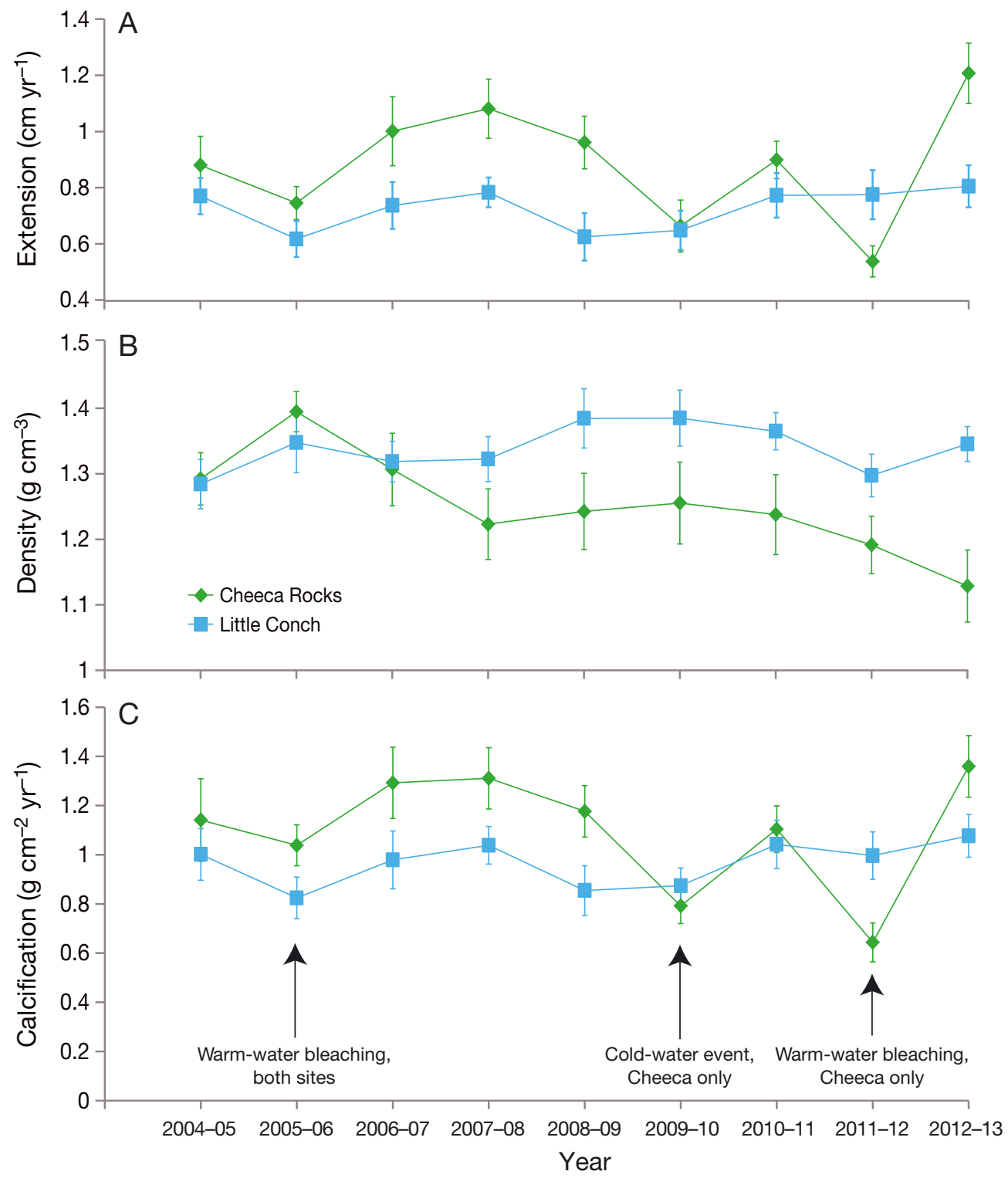

Fig. 3. (A) Mean linear extension, (B) skeletal density, and (C) calcification rate per year from 2004 to 2013 for Orbicella faveolata at Cheeca Rocks and Little Conch Reef. Error bars = $\mathrm{SE}$ of the mean ing or reduce photo-oxidative damage during warmwater stress via shading (Lirman \& Fong 2007, Zepp et al. 2008, Ayoub et al. 2009, Soto et al. 2011). Recently, it was discovered that aragonite saturation state $\left(\Omega_{\text {arag }}\right)$ is elevated inshore, another possible contributing factor (Manzello et al. 2012).

The corals at Cheeca Rocks are tolerant of very warm conditions, as they experienced temperatures $>1^{\circ} \mathrm{C}$ greater than the bleaching threshold at MLRF1 each summer from 2010 to 2012 (Fig. 2, Table 1). Corals do have higher bleaching thresholds in turbid environments (Jokiel \& Brown 2004), but it has not yet been tested if this is due to thermal acclimatization/adaptation of the corals, shading, or an interaction of the two factors. The 2005 bleaching event sim- ilarly impacted the growth of $O$. faveolata at both the inshore and offshore sites, suggesting that if shading is promoting the high inshore coral cover, it may not be reflected in the growth of individual corals.

Elevated lipid reserves, linked to higher heterotrophic feeding, occur in corals on nearshore, turbid reefs in Australia (Anthony 2006). Given that increased heterotrophy during bleaching can lead to higher survival and quicker recovery (Grottoli et al. 2006, Rodrigues \& Grottoli 2007), this has been explored as a potential mechanism promoting the high inshore coral cover. However, the data obtained to date were inconclusive because coral lipid sources (heterotrophic versus autotrophic) were highly variable for the same species on the same reef, overshad- 
Table 2. Mean linear extension $\left(\mathrm{cm} \mathrm{yr}^{-1}\right)$, skeletal density $\left(\mathrm{g} \mathrm{cm}^{-3}\right)$, and calcification $\left(\mathrm{g} \mathrm{cm}^{-2} \mathrm{yr}^{-1}\right)$ at Cheeca Rocks and Little Conch Reef from 2004 to 2013 with and without the annual increments of growth associated with thermal stress specific to only Cheeca Rocks (2009-2010, 2011-2012). SEM: standard error of the mean

\begin{tabular}{|lcccc|}
\hline Site & Years & $\begin{array}{c}\text { Linear extension } \\
\text { Mean }( \pm \text { SEM) }\end{array}$ & $\begin{array}{c}\text { Skeletal density } \\
\text { Mean }( \pm \text { SEM) }\end{array}$ & $\begin{array}{c}\text { Calcification } \\
\text { Mean }( \pm \text { SEM) }\end{array}$ \\
\hline Cheeca Rocks & $\begin{array}{l}\text { 2004 to 2013 } \\
\text { Stress years removed }\end{array}$ & $0.89(0.070)$ & $1.25(0.025)$ & $1.10(0.080)$ \\
Little Conch & 2004 to 2013 & $0.97(0.056)$ & $1.26(0.031)$ & $1.20(0.045)$ \\
& Stress years removed & $0.73(0.025)$ & $1.34(0.012)$ & $0.97(0.030)$ \\
& & $0.73(0.029)$ & $1.34(0.012)$ & $0.97(0.037)$ \\
\hline
\end{tabular}

owing any differences across sites (Teece et al. 2011). The importance of heterotrophy during and after bleaching has yet to be explored; thus, heterotrophy cannot be ruled out as a factor in the inshore-offshore patterns, as it may contribute to the rapid recovery in growth inshore after thermal stress.

Elevated nutrients at the inshore sites may also be contributing to the faster growth/calcification and lower skeletal density, as this has been shown in the field and experimentally (Edinger et al. 2000, Dunn et al. 2012). Nutrient levels are significantly elevated inshore (Boyer \& Briceño 2006, Lirman \& Fong 2007). Corals respond to declines in cross-shelf water quality (e.g. increase in suspended sediment, elevated nutrients, and decrease in light availability) by extending their skeleton at the same or greater rates as unaffected corals, but generally at the expense of skeletal density (Carricart-Ganivet \& Merino 2001). Because of this depressed density inshore, calcification tends to be highest offshore. Cheeca Rocks did exhibit depressed skeletal density and elevated extension, but calcification was also elevated, differing from typical 'stretch-modulation' (CarricartGanivet \& Merino 2001).

The seasonally elevated inshore $\Omega_{\text {arag }}$ during the spring and summer may also contribute to the higher rates of calcification (Manzello et al. 2012). Springtime mean inshore $\Omega_{\text {arag }}$ in the upper FRT was 4.7 from 2009 to 2011 . Conversely, $\Omega_{\text {arag }}$ on offshore reefs was 3.9 at the same time. The majority of reefs studied to date exhibit average $\Omega_{\text {arag }}$ values $<4$, usually around 3.3 to 3.8 (Manzello 2010b). Fewer studies have been conducted in the Atlantic than in the Pacific, but the presently available data show similar $\Omega_{\text {arag }}$ values in both oceans. Samples collected from reefs in St. John and St. Thomas during the summer of 2013 had a mean (standard error of the mean) $\Omega_{\text {arag }}=3.9(0.015)(\mathrm{n}=72, \mathrm{D}$. P. Manzello unpubl. data). In La Parguera Puerto Rico, average $\Omega_{\text {arag }}$ collected bi-weekly for 3 yr from 2009 to 2011 was 3.6 (D. K. Gledhill unpubl. data). The inshore-offshore gradient on the FRT is opposite to what has been shown for other reef environments, as $\Omega_{\text {arag }}$ usually declines from the open ocean into lagoonal environments (Suzuki \& Kawahata 2003). The fact that calcification is highest inshore in the Florida Keys, differing from classic 'stretch-modulation' (Carricart-Ganivet \& Merino 2001), may be a result of the elevated $\Omega_{\text {arag }}$ inshore.

Future research is needed to determine which of the aforementioned factors are driving the faster inshore calcification and how this relates to the persistence of the high coral cover at these sites. This research will yield valuable insights for coral reef managers as they work to conserve these valuable resources with climate change and ocean acidification.

Acknowledgements. The authors are indebted to NOAA's Coral Reef Conservation Program and Ocean Acidification Program for supporting this work. We thank the Florida Keys National Marine Sanctuary for allowing this work to take place (Permits \#FKNMS-2008-091 and \#FKNMS2011-049). M. Doig provided assistance with coring. Joanne Delaney, in particular, was incredibly helpful with permitting. We thank 3 anonymous reviewers and topic editor P. J. Edmunds for comments that substantially improved the manuscript. The manuscript contents are solely the opinions of the authors and do not constitute a statement of policy, decision, or position on behalf of NOAA or the US Government.

\section{LITERATURE CITED}

Anthony KRN (2006) Enhanced energy status of corals on coastal, high-turbidity reefs. Mar Ecol Prog Ser 319: 111-116

Ayoub L, Hallock P, Coble P (2009) Colored dissolved organic material increases resiliency of coral reefs by controlling exposure to UVR. Proc 11th Int Coral Reef Symp 16:572-576

Boyer JN, Briceño HO (2006) FY2005 annual report of the Water Quality Monitoring Project for the Water Quality Program of the Florida Keys National Marine Sanctuary. Technical Report \#T-327. Southeast Environmental Research Center, Florida International University, Miami, FL 
Bruckner AW, Bruckner RJ (2006) The recent decline of Montastraea annularis (complex) coral populations in western Curacao: a cause for concern? Rev Biol Trop 54: 45-58

Bruckner AW, Hill R (2009) Ten years of change to coral communities off Mona and Desecheo Islands, Puerto Rico, from disease and bleaching. Dis Aquat Org 87: $19-31$

Carricart-Ganivet JP, Merino M (2001) Growth responses of the reef-building coral Montastraea annularis along a gradient of continental influence in the southern Gulf of Mexico. Bull Mar Sci 68:133-146

Causey BD (2001) Lessons learned from the intensification of coral bleaching from 1980-2000 in the Florida Keys, USA. In: Salm RV, Coles SL (eds) Proceedings of the Workshop on Mitigating Coral Bleaching Impact Through MPA Design. The Nature Conservancy, Honolulu, HI, p 60-66

Colella MA, Ruzicka RR, Kidney JA, Morrison JM, Brinkhuis VB (2012) Cold-water event of January 2010 results in catastrophic benthic mortality on patch reefs in the Florida Keys. Coral Reefs 31:621-632

CREMP (2014) Florida Keys National Marine Sanctuary Water Quality Protection Program, Coral Reef Evaluation and Monitoring Program (CREMP). Data Integration System: 2011 Non-generic raw data. Available at http:// ocean.floridamarine.org/fknms_wqpp/pages/cremp.html (accessed 29 July 2014)

Dodge RE, Brass GW (1984) Skeletal extension, density and calcification of the reef coral Montastrea annularis: St. Croix, US Virgin Islands. Bull Mar Sci 34: 288-307

> Dunn JG, Sammarco PW, LaFleur G (2012) Effects of phosphate on growth and skeletal density in the scleractinian coral Acropora muricata: a controlled experimental approach. J Exp Mar Biol Ecol 411:34-44

Dustan P, Halas JC (1987) Changes in the reef-coral community of Carysfort Reef, Key Largo, Florida: 1974 to 1982. Coral Reefs 6:91-106

Edinger EN, Limmon GV, Jompa J, Widjatmoko W, Heikkoop JM, Risk MJ (2000) Normal coral growth rates on dying reefs: Are coral growth rates good indicators of reef health? Mar Pollut Bull 40:404-425

Edmunds PJ, Elahi R (2007) The demographics of a 15 year decline in cover of the Caribbean reef coral Montastraea annularis. Ecol Monogr 77:3-18

FRRP (2014) Florida Reef Resilience Program data. Available at http://frrp.org/data/ (accessed 29 July 2014)

Gardner TA, Côté IM, Gill JA, Grant A, Watkinson AR (2003) Long-term region-wide declines in Caribbean corals. Science 301:958-960

Grottoli AG, Rodrigues LJ, Palardy JE (2006) Heterotrophic plasticity and resilience in bleached corals. Nature 440:1186-1189

Helmle KP, Kohler K, Dodge RE (2002) Relative optical densitometry and the coral X-radiograph densitometry system: Coral XDS. Int Soc Reef Studies 2002 European Meeting, Cambridge. Available at www.nova.edu/ocean/ coralxds/index.html

> Helmle KP, Dodge RE, Swart PK, Gledhill DK, Eakin CM (2011) Growth rates of Florida corals from 1937 to 1996 and their response to climate change. Nat Commun 2: 215

Hudson JH (1981) Growth rates of Montastraea annularis: a record of environmental change in Key Largo Coral Reef
Marine Sanctuary, Florida. Bull Mar Sci 31:444-459

Hudson JH (1982) Response of Montastrea annularis to environmental change in the Florida Keys. Proc 4 th Intl Coral Reef Symp 2:444-459

> Hudson JH, Shinn EA, Halley RB, Lidy B (1976) Sclerochronology: a tool for interpreting past environments. Geology 4:361-364

Jaap WC (1979) Observation on zooxanthellae expulsion at Middle Sambo Reef, Florida Keys. Bull Mar Sci 29: 414-422

Jaap WC (1985) An epidemic zooxanthellae expulsion during 1983 in the lower Florida Keys coral reefs: hyperthermic etiology. Proc 5th Intl Coral Reef Symp 6:143-148

Jokiel PL, Brown EK (2004) Global warming, regional trends and inshore environmental conditions influence coral bleaching in Hawaii. Glob Change Biol 10:1627-1641

> Kemp DW, Oakley CA, Thornhill DJ, Newcomb LA and others (2011) Catastrophic mortality on inshore coral reefs of the Florida Keys due to severe low-temperature stress. Glob Change Biol 17:3468-3477

Lirman D, Fong P (2007) Is proximity to land-based sources of coral stressors an appropriate measure of risk to coral reefs? An example from the Florida Reef Tract. Mar Pollut Bull 54:779-791

Lirman D, Schopmeyer S, Manzello D, Gramer LJ and others (2011) Severe 2010 cold-water event caused unprecedented mortality to corals of the Florida Reef Tract and reversed previous survivorship patterns. PLoS ONE 6: e23047

Lough JM, Barnes DJ (1997) Several centuries of variation in skeletal extension, density and calcification in massive Porites colonies from the Great Barrier Reef: a proxy for seawater temperature and a background of variability against which to identify unnatural change. J Exp Mar Biol Ecol 211:29-67

> Manzello DP (2010a) Coral growth with thermal stress and ocean acidification: lessons from the eastern Pacific. Coral Reefs 29:749-758

Manzello DP (2010b) Ocean acidification hot spots: spatiotemporal dynamics of the seawater $\mathrm{CO}_{2}$ system of eastern Pacific coral reefs. Limnol Oceanogr 55:239-248

- Manzello DP, Berkelmans R, Hendee JC (2007a) Coral bleaching indices and thresholds for the Florida Reef Tract, Bahamas, and St. Croix, US Virgin Islands. Mar Pollut Bull 54:1923-1931

- Manzello DP, Brandt M, Smith TB, Lirman D and others (2007b) Hurricanes benefit bleached corals. Proc Natl Acad Sci USA 104:12035-12039

Manzello DP, Enochs IC, Melo N, Gledhill DK, Johns EM (2012) Ocean acidification refugia of the Florida Reef Tract. PLoS ONE 7:e41715

Marszalek DS, Babashoff G, Noel MR, Worley DR (1977) Reef distribution in South Florida. Proc 3rd Int Coral Reef Symp 2:223-229

Pandolfi JM, Jackson JBC, Baron N, Bradbury RH and others (2005) Are US coral reefs on the slippery slope to slime? Science 307:1725-1726

Porter JW, Meier OW (1992) Quantification of loss and change in Floridian reef coral populations. Am Zool 32: 625-640

Precht WF, Miller SL (2007) Ecological shifts along the Florida Reef Tract: the past as the key to the future. In: Aronson RB (ed) Geological approaches to coral reef ecology. Springer, New York, NY, p 237-312

Rodrigues LJ, Grottoli AG (2007) Energy reserves and 
metabolism as indicators of coral recovery from bleaching. Limnol Oceanogr 52:1874-1882

Ruzicka RR, Colella MA, Porter JW, Morrison JM and others (2013) Temporal changes in benthic assemblages on Florida Keys reefs 11 years after the 1997/1998 El Niño. Mar Ecol Prog Ser 489:125-141

Shinn EA (1966) Coral growth rate, an environmental indicator. J Paleontol 40:233-240

Somerfield PJ, Jaap WC, Clarke KR, Callahan M and others (2008) Changes in coral communities among the Florida Keys, 1996-2003. Coral Reefs 27:951-965

Soto IM, Muller-Karger FE, Hallock P, Hu C (2011) Sea surface temperature variability in the Florida Keys and its relationship to coral cover. J Mar Biol 2011:981723

Suzuki A, Kawahata H (2003) Carbon budget of coral reef systems: an overview of observations in fringing reefs, barrier reefs and atolls in the Indo-Pacific regions. Tellus $55: 428-444$

Editorial responsibility: Peter Edmunds, Northridge, California, USA
Teece MA, Estes B, Gelsleichter E, Lirman D (2011) Heterotrophic and autotrophic assimilation of fatty acids by two scleractinian corals, Montastraea faveolata and Porites astreoides. Limnol Oceanogr 56:1285-1296

Toth LT, van Woesik R, Murdoch TJ, Smith SR, Ogden JC, Precht WF, Aronson RB (2014) Do no-take reserves benefit Florida's corals? 14 years of change and stasis in the Florida Keys National Marine Sanctuary. Coral Reefs 33: 565-577

Walter C (2014) Florida Keys Coral Bleaching Early Warning Network (BLEACHWATCH), current conditions reports. Available at isurus.mote.org/Keys/current_conditions. phtml (accessed 6 June 2014)

> Zepp RG, Shank GC, Stabenau E, Patterson KW and others (2008) Spatial and temporal variability of solar ultraviolet exposure of coral assemblages in the Florida Keys: importance of colored dissolved organic matter. Limnol Oceanogr 53:1909-1922

Submitted: June 12, 2014; Accepted: October 21, 2014 Proofs received from author(s): January 20, 2015 